Vol. 1 No. 3 November 2021 e-ISSN : 2797-1031 | p-ISSN : 2797-0744

\title{
GERAK SENDI PEMBELAJARAN PAKEM UNTUK MENINGKATKAN DAYA INGAT SISWA PADA PEMBELAJARAN SENDI MANUSIA
}

\author{
AMIRUDDIN \\ SMP Negeri 1 Anggaberi, Kab. Konawe \\ amiruddinmm1972@gmail.com
}

\begin{abstract}
ABSTRAK
Tujuan best practice ini adalah untuk mengetahui bagaimana implementasi pendekatan PAKEM gerak sendi dalam meningkatkan daya ingat belajar siswa kelas VIII A SMP Negeri 1 Anggaberi Kabupaten Konawe pada pembahasan materi jenis-jenis sendi manusia, mata pelajaran Ilmu Pengetahuan Alam. Hasil kegiatan pembelajaran menunjukkan bahwa penerapan pendekatan belajar Pakem dengan gerak sendi dapat meningkatkan kemampuan mengingat materi pelajaran jenis-jenis sendi manusia pada siswa kelas VIII A SMP Negeri 1 Anggaberi. Hasil kuis mengidentifikasi jenis sendi pada manusia sebelum penerapan pembelajaran Pakem gerak sendi pada kegiatan pembelajaran sebelumnya menunjukkan ratarata persantase kemampuan mengingat materi mengidentifikasi materi hanya mencapai nilai $50 \%$, masih di bawah nilai KKM yang ditetapakan pada jenis sendi pada manusia, dan mengalami peningkatan setelah kegiatan pembelajaran yang menerapkan pendekatan Pakem gerak sendi hasil kuis mengingat materi mengidentifikasi sendi pada manusia persentase analisis hasil kuis mencapai nilai $85 \%$, di atas KKM yang telah ditetapkan pada materi jenis sendi pada manusia.
\end{abstract}

Kata Kunci: Pakem, daya ingat, sendi pada manusia, gerak sendi

\section{ABSTRACT}

The purpose of this best practice is to find out how the implementation of the PAKEM approach to joint motion in improving the learning memory of class VIII A students of SMP Negeri 1 Anggaberi, Konawe Regency in the discussion of the types of human joints in the subject of Natural Sciences. The results of the learning activities indicate that the application of the Pakem learning approach with joint motion can improve the ability to remember the subject matter of the types of human joints in class VIII A students of SMP Negeri 1 Anggaberi. The results of the quiz on identifying the types of joints in humans before the application of the joint movement grip learning in previous learning activities showed the average percentage of ability to remember materials to identify materials only reached a value of $50 \%$, still below the KKM value set for the types of joints in humans, and increased after learning activities that apply the gripping joint motion approach to the quiz results considering the material on identifying joints in humans, the percentage of analysis of quiz results reaches a value of $85 \%$, above the KKM that has been set on the material for joint types in humans.

Keywords: grip, memory, joints in humans, joint motion

\section{PENDAHULUAN}

Ada tiga faktor yang mempengaruhi kebermaknaan dalam suatu pembelajaran, yaitu struktur kognitif yang ada, stabilitas dan kejelasan pengetahuan dalam suatu bidang studi tertentu dan pada waktu tertentu. Belajar bermana dapat diidentifikasi berdasarkan ciri-cirinya, Nasution (2003) memaparkan sebagai berikut : (1) Menjelaskan hubungan atau relevansi bahan-bahan baru dengan bahan-bahan lama. (2) Lebih dulu diberikan ide yang paling umum dan kemudian hal-hal yang lebih terperinci, (3) Menunjukkan persamaan dan perbedaan antara bahan baru dengan bahan lama, (4) Mengusahakan agar ide yang telah ada dikuasai sepenuhnya sebelum ide yang baru disajikan, (5) Informasi yang dipelajari secara bermakna dapat lebih lama untuk diingat. (6) Informasi yang dipelajari secara bermakna memudahkan proses belajar berikutnya untuk materi pelajaran yang mirip, (7) Informasi yang dipelajari secara bermakna mempermudah belajar hal-hal yang mirip walaupun telah terjadi lupa. Di samping itu, 
kebermaknaan potensial materi pelajaran bergantung kepada dua faktor, yaitu (1) materi itu harus memiliki kebermaknaan logis, dan (2) gagasan-gagasan yang relevan harus terdapat dalam struktur kognitif peserta didik. Menurut (Samani, 2007) mengemukakan bahwa apapun metode pembelajarannya, maka harus bermakna (meaningfull learning). Pembelajaran bermakna merupakan suatu proses mengaitkan informasi baru pada konsep-konsep relevan yang terdapat dalam struktur kognitif seseorang. Struktur kognitif ialah fakta-fakta, konsepkonsep dan generalisasi-generalisasi yang telah dipelajari dan diingat siswa. (Suparno, 1997) mengatakan, bahwa pembelajaran bermakna adalah suatu proses pembelajaran dimana informasi baru dihubungkan dengan struktur pengertian yang sudah dipunyai seorang yang sedang dalam proses pembelajaan. Pembelajaran bermakan terjadi bila siswa mencoba menghubungkan fenomena baru ke dalam struktur pengetahuan mereka. Artinya, bahan pelajaran itu harus cocok dengan kemampuan siswa dan harus relevan dengan struktur kognitif yang dimiliki siswa. Oleh karena itu, pelajaran harus dikaitkan dengan konsep-konsep yang sudah dimilki siswa, sehingga konsep-konsep baru tersebut benar-benar terserap olehnya. Dengan demikian, faktor intelektual emosional siswa terlibat dalam kegiatan pembelajaran. Pembelajaran bermakna adalah pembelajaran yang menyenangkan yang akan memiliki keunggulan dalam meraup segenap informasi secara utuh sehingga konsekuensi akhir meningkatkan kemampuan siswa. Pembelajaran bermakna merupakan suatu proses dikaitkannya informasi baru pada konsep-konsep relevan yang terdapat dalam struktur kognitif seseorang. Pembelajaran bermakna ditandai oleh terjadinya hubungan antara aspek-aspek, konsep-konsep, informasi atau situasi baru dengan komponen-komponen yang relevan di dalam struktur kognitif siswa. Proses belajar tidak sekadar menghafal konsep-konsep atau fakta-fakta belaka, tetapi merupakan kegiatan menghubungkan konsep-konsep untuk menghasilkan pemahaman yang utuh, sehingga konsep yang dipelajari akan dipahami secara baik dan tidak mudah dilupakan. Dengan demikian, agar terjadi belajar bermakna maka guru harus selalu berusaha mengetahui dan menggali konsep-konsep yang telah dimiliki peserta didik dan membantu memadukannya secara harmonis konsep-konsep tersebut dengan pengetahuan baru yang akan diajarkan. Jadi belajar akan lebih bermakna jika anak mengalami langsung apa yang dipelajarinya dengan mengaktifkan lebih banyak indera daripada hanya mendengarkan guru menjelaskan.

PAKEM adalah singkatan dari Pembelajaran Aktif, Kreatif, Efektif, dan Menyenangkan, disebut demikian karena pembelajaran ini dirancang agar mengaktifkan siswa dalam pembelajaran, mengembangkan kreativitasnya, sehingga efektif namun tetap menyenangkan. Aktif dimaksudkan bahwa dalam proses pembelajaran guru harus menciptakan suasana sedemikian rupa sehingga siswa aktif bertanya, mempertanyakan, dan mengemukakan gagasan. Peran aktif dari siswa sangat penting dalam rangka pembentukan generasi yang kreatif, yang mampu menghasilkan sesuatu untuk kepentingan dirinya dan orang lain. Menyenangkan adalah suasana belajar-mengajar yang menyenangkan sehingga siswa memusatkan perhatiannya secara penuh pada belajar. Keadaan aktif dan menyenangkan tidaklah cukup jika proses pembelajaran tidak efektif, yaitu tidak menghasilkan apa yang harus dikuasai siswa setelah proses pembelajaran berlangsung, sebab pembelajaran memiliki sejumlah tujuan pembelajaran yang harus dicapai. Guru dituntut untuk secara profesional merancang pembelajaran efektif dan bermakna (menyenangkan), mengorganisasikan pembelajaran, memilih pendekatan pembelajaran yang tepat, menentukan prosedur pembelajaran dan pembentukan kompetensi secara efektif, serta menetapkan kriteria keberhasilan. PAKEM bertujuan untuk menciptakan lingkungan belajar yang kaya, membekali siswa dengan keterampilan-keterampilan, pengetahuan dan sikap untuk hidup. PAKEM didasarkan pada teori belajar konstruktivisme dalam pembelajaran. Teori ini dikembangkan oleh J.Piaget. Teori belajar Konstruktivisme merupakan teori belajar yang didasarkan pada ide bahwa siswa harus menjadikan informasi atau pengetahuan itu miliknya sendiri. Teori ini memandang bahwa setiap individu memiliki kemampuan untuk mengkonstruksi sendiri pengetahuannya dengan jalan berinteraksi secara terus-menerus dengan lingkungannya. 
Perkembangan teori belajar berdasarkan riset selama hampir 100 tahun secara bertahap mengubah paradigma tentang bagaimana seharusnya guru mengajar dan/atau peserta didik belajar. Teori-teori belajar yang ditemukan pada akhirnya berkulminasi pada teori konstruktivisme. Teori konstruktivisme pada dasarnya, (1) menyesuaikan aplikasi teori dengan cara kerja otak seperti yang dilaporkan oleh temuan riset neurosains, (2) mengadopsi hasil riset biologi tentang cara kerja tubuh, (3) mengadopsi temuan riset fisika tentang alam semesta yang bersinergi sebagai suatu sistem, (4) menyelaraskan aplikasi nilai-nilai dan pandangan historis, kultural, dan sosial, terutama melalui bahasa, dalam penerapan belajar aktif, baik dari hasil riset ilmu-ilmu sosial maupun dari segi konsepsi filsafat, teori agama dan humaniora, dan (5) mengadaptasi temuan dan praktis yang relevan dari dunia kerja.

Secara khusus PAKEM dapat dilihat dari kegiatan pembelajaran sebagai berikut: ciriciri aktif diantaranya, (1) situasi kelas yang menantang siswa untuk melakukan kegiatan belajar secara bebas tapi terkendali, (2) guru tidak mendominasi pembicaraan, tetapi lebih banyak memberikan rangsangan berpikir kepada siswa untuk memecahkan masalah, (3) guru menyediakan dan mengusahakan sumber belajar bagi siswa, (4) hubungan guru dengan siswa sifatnya harus mencerminkan hubungan manusia bagaikan hubungan bapak-anak, bukan hubungan pimpinan dan bawahan, guru menempatkan diri sebagai pembimbing semua siswa yng memerlukan bantuan manakala mereka menghadapi persoalan belajar, (5) belajar tidak hanya dilihat dan diukur dari segi hasil yang dicapai siswa tetapi juga dilihat dan diukur dari segi proses belajar yang dilakukan siswa, (6) adanya keberanian siswa mengajukan pendapatnya melalui pertanyaan atau pernyataan gagasannya, baik yang diajukan kepada guru maupun kepada siswa lainnya dalam pemecahan masalah belajar,dan (7) guru senantiasa menghargai pendapat siswa, terlepas dari benar atau salah, dan tidak diperkenankan membunuh, mengurangi atau menekanpendapat siswa didepan siswa lainnya. Ciri-ciri kreatif diantaranya, menciptakan kegiatan belajar yang beragam, memenuhi berbagai tingkat kemampuan siswa, memanfaatkan berbagai sumber dan media belajar yang berfariasi, mampu menghasilkan sesuatu untuk kepentingan dirinya dan orang lain, dan mampu mengembangkan atau menciptakan sesuatu yang baru. Ciri-ciri pembelajaran efektif diantaranya adalah, mencapai kompetensi pembelajaran., bukan hanya sekedar bermain saja, tepat sasaran dan sesuai dengan waktu yang tersedia, dan menghasilkan apa yang harus dikuasai oleh siswa.

Menurut (Made Pidarta, 2007) untuk mengelola kelas secara efektif perlu diperhatikan hal-hal sebagai berikut: (1) kelas adalah kelompok kerja yang diorganisasi untuk tujuan tertentu, yang dilengkapi oleh tugas-tugas dan diarahkan oleh guru, (2) dalam situasi kelas, guru bukan tutor untuk satu anak pada waktu tertentu, tetapi bagi semua anak atau kelompok, (3) kelompok mempunyai perilaku sendiri yang berbeda dengan perilaku-perilaku masing-masing individu dalam kelompok itu, (4) Kelompok kelas menyisipkan pengaruhnya kepada anggotaanggota. Pengaruh yang jelek dapat dibatasi oleh usaha guru dalam membimbing kelas, (5) praktik guru waktu belajar cenderung terpusat pada hubungan guru dan siswa, dan (6) struktur kelompok, pola komunikasi, dan kesatuan kelompok ditentukan cara mengelola, baik untuk mereka yang tertarik pada sekolah maupun bagi mereka yang apatis, masa bodoh atau bermusuhan. Sedangkan ciri-ciri pembelajaran yang menyenangkan adalah belajar tanpa tekanan, pembelajarannya dapat dinikmati, menyenangkan, mengasyikan, menguatkan, mencerdaskan, memberikan tantangan kepada siswa untuk berfikir, mencoba, belajar lebih lanjut, penuh dengan percaya diri, dan mandiri untuk mengembangkan potensi positifnya secara optimal, serta menjadikan manusia berkarakter penuh percaya diri, menjadi dirinya sendiri dan mempunyai semangat kompetitif dalam nuansa kebersamaan.

(Sudirman \& Andriyani, 2002), bahwa hasil belajar dapat diartikan sebagai taraf kemampuan aktual yang bersifat terukur berupa perbuatan yang dicapai dari apa yang dipelajari di sekolah. Hasil belajar merupakan hasil dari suatu interaksi tindak belajar dan tindak mengajar. Dari sisi guru, tindak mengajar diaktiri dengan proses evaluasi hasil belajar. Dari sisi siswa hasil belajar merupakan berakhirnya penggal dan puncak proses belajar. Hasil belajar, untuk sebagian orang adalah berkat tindak guru, suatu pencapaian tujuan pengajaran. Pada 
bagian lain, merupakan peningkatan kemampuan mental siswa (Dimyati \& Mudjiono, 2006: 3). Dalam bidang studi Fisika hasil belajar yang dimaksud adalah tingkat penguasaan materi pelajaran setelah proses evaluasi diberikan, sebagai tolak ukur kemampuan siswa setelah proses belajar-mengajar berlangsung, dapat disimpulkan bahwa pengukuran hasil belajar berfungsi untuk mengetahui tercapai tidaknya indikator pembelajaran dan mengetahui tingkat penguasaan bahan pelajaran yang harus dikuasai siswa serta untuk mengetahui efektifitas model pengajaran yang digunakan dalam proses belajar-mengajar. Aktifitas belajar siswa sesuai pendapat para ahli bahwa, aktivitas belajar adalah segala kegiatan yang dilakukan dalam proses interaksi (guru dan siswa) dalam rangka mencapai tujuan belajar. Aktivitas yang dimaksudkan di sini penekanannya adalah pada siswa, sebab dengan adanya aktivitas siswa dalam proses pembelajaran terciptalah situasi belajar aktif, seperti yang dikemukakan Rochman Natawijaya (Depdiknas, 2005 : 31), belajar aktif adalah "Suatu sistem belajar mengajar yang menekankan keaktivan siswa secara fisik, mental intelektual dan emosional guna memperoleh hasil belajar yang berupa perpaduan antara aspek kognitif, afektif dan psikomotor". Hal lain yang dapat meningkatkan hasil belajar siswa adalah pendekatan pembelajaran Pakem

Dalam kegiatan proses belajar mengajar mata pelajaran Ilmu Pengetahuan Alam (IPA) siswa kelas VIII SMP Negeri 1 Anggaberi materi sendi ada permaalahan yang penulis sering temukan sebagai guru mata pelajaran IPA, yaitu proses pembelajaran materi sendi. Dimana sebagian besar siswa belum mampu mengingat dengan baik jenis-jenis sendi ketika guru melakukan kuis kepada siswa, hanya sekitar 50\% dari jumlah siswa yang mampu mengingat kembali jenis-jenis sendi ketika dilaksanakan kuis mengidentifikasi jenis jenis sendi pada manusia. Hal ini tentu perlu pemecahan masalah karena materi sendi merupakan materi yang mempelajari bagian tubuh siswa itu sendiri, dan sangat diharapkan siswa mampu mengidentifikasi jenis sendi pada dirinya secara tepat.

Untuk memecahkan masalah pembelajaran di atas penulis sebagai guru mata pelajaran IPA melaksanakan kegiatan pembelajaran Pakem gerak sendi untuk meningkatkan daya ingat siswa dalam menyerat materi pelajaran. Gerak sendi adalah gerak tubuh siswa ketika guru menyebutkan jenis sendi, artinya ketika guru menyebut salah satu jenis sendi maka siswa menunjukkan dengan gerakan sendi yang dimadsuk. Kegiatan gerak sendi ini juga bisa meningkatkan aktifitas belajar siswa dan menciptakan kondisi belajar siswa yang menyenangkan.

\section{METODE PELAKSANAAN}

Untuk memecahkan masalah pembelajaran di atas penulis sebagai guru mata pelajaran IPA melaksanakan kegiatan pembelajaran Pakem gerak sendi untuk meningkatkan daya ingat siswa dalam menyerat materi pelajaran. Gerak sendi adalah gerak tubuh siswa ketika guru menyebutkan jenis sendi, artinya ketika guru menyebut salah satu jenis sendi maka siswa menunjukkan dengan gerakan sendi yang dimadsuk. Kegiatan gerak sendi ini juga bisa meningkatkan aktifitas belajar siswa dan menciptakan kondisi belajar siswa yang menyenangkan. Pada tahap ini guru sebagai peneliti mempersiapkan hal-hal yang dibutuhkan dalam pelaksanaan kegiatan pembelajaran. Adapun tahap kegiatan yang akan dilaksanakan adalah, (1) membuat scenario pembelajaran berupa Rencana Pelaksanaan Pembelajaran (RPP) jenis-jenis sendi pada manusia, (2) memeriksa kesiapan sumber belajar seperti buku siswa, buku referensi yang relevan, dan (3) membuat instrumen kuis untuk mengukur daya ingat siswa untuk mengidentifikasi jenis-jenis sendi pada manusia.

Adapun kegiatan yang dilaksanakan pada tahap ini adalah melaksanakan scenario pembelajaran pada Rencana Pelaksanaan Pembelajaran (RPP) jenis -jenis sendi manusia dengan pendekatan pakem. Pada kegiatan pembelajaran ini guru mengidentifikasi jenis-jenis sendi melalui gerakan sesuai sendi yang diidentifikasi. Misalnya ketika guru mengidentifikasi jenis sendi engsel maka guru menggerakkan bagian sendi siku dan sendi lutut. Proses observasi dilakukan sejak awal hingga akhir pembelajaran. proses observasi melalui pengamatan guru sebagai peneliti yang mengamati interaksi siswa selama proses belajar mengajar berlangsung. 
Vol. 1 No. 3 November 2021 e-ISSN : 2797-1031 | p-ISSN : 2797-0744

Evaluasi berupa kuis bertujuan untuk melihat peningkatan daya ingat siswa menyerap materi pelajaran dengan melaksanakan pendekatan Pakem. Apakah daya ingat siswa menyerap materi meningkat atau lebih tinggi dengan melaksanakan gerak sendi pembelajaran Pakem pada pembahasan materi jenis-jenis sendi manusia. Evaluasi berupa kuis dilaksanakan setiap akhir pembelajaran dalam bentuk pertanyaan lisan atau kuis.

Untuk mengukur daya ingat siswa menyerap materi pelajaran secara kognitif dianalisis secara deskriptif analitif yaitu dengan menyajikan dalam bentuk tabel prosentase. Penyajian data dalam bentuk prosentase selanjutnya dideskripsikan dan diambil kesimpulan berdasarkan kriteria yang telah ditentukan. Besarnya presentase menunjukkan pada kriteria informasi yang diungkapkan, adapun analisis dengan menggunakan tabel di bawah ini (Lusia G.S \& Sukadari, 2020)

Tabel: 1 Kriteria Penilaian Kemampuan Mengingat Materi Pelajaran Siswa

\begin{tabular}{|c|c|c|}
\hline No & Interval NA (Skala: 0- 100) & Kriteria \\
\hline 1 & $91 \leq X \leq 100$ & Sangat Baik \\
\hline 2 & $81 \leq X \leq 90$ & Baik \\
\hline 3 & $75 \leq X \leq 80$ & Cukup \\
\hline 4 & $0 \leq X \leq 74$ & Kurang \\
\hline
\end{tabular}

Indikator keberhasilan pelaksanaan pembelajaran adalah apabila daya ingat siswa menyerap materi pelajaran secara kognitif meningkat minamal $75 \%$, artinya $75 \%$ dari jumlah siswa yang mengikuti pembelajaran IPA materi jenis-jenis sendi pada manusia mencapai KKM mata pelajaran IPA indikator materi sendi pada manusia.

\section{HASIL DAN PEMBAHASAN}

Hasil kegiatan pembelajaran menunjukkan terjadinya peningkatan kemampuan menyerap materi pelajaran pada pembahasan materi jenis- jenis sendi pada manusia siswa kelas VIII A SMP Negeri 1 Anggaberi pada kegiatan pembelajaran yang dilaksanakan pada bulan Agustus tahun 2021. Berdasarkan data hasil penilaian kemampuan mengingat jenis-jenis sendi pada manusia sebelum penerapan pendekatan gerak sendi pembelajaran pakem menunjukkan rata-rata daya serap materi pelajaran untuk mengingat kembali materi pelajaran melalui pertanyaan kuis hanya mencapai 50\% masih di bawah nilai KKM materi sendi pada manusia.

Tabel 2: Data Hasil Belajar Materi Sendi Pada Manusia 2 Tahun Terakhir Siswa Kelas VIII SMPN 1 Anggaberi.

\begin{tabular}{|c|c|c|c|c|}
\hline No & Tapel & Kelas & Jml Siswa & Prosentase Tuntas \\
\hline 1 & $2019 / 2020$ & VIII A & 28 & $55 \%$ \\
\hline 2 & $2020 / 2021$ & VIII A & 26 & $45 \%$ \\
\hline
\end{tabular}

Sumber: Analisis Hasil Pembelajaran Mapel IPA SMPN 1 Anggaberi

Dampak setelah penerapan pendekatan kegiatan pembelajaran pakem gerak sendi, menunjukkan adanya peningkatan kemampuan mengingat materi pelajaran jenis-jenis sendi pada manusia pada kegiatan pembelajaran mata pelajaran IPA yang dilaksanakan pada semester ganjil tahun pelajaran 2021/2022 dengan prosentase analisis hasil kuis kemampuan mengingat pelajaran jenis-jenis sendi pada manusia mencapai nilai $85 \%$. Untuk mengetahui peningkatan persentase kemampuan mengingat materi pelajaran jenis-jenis sendi pada manusia siswa kelas VIII A SMP Negeri 1 Anggaberi dapat dilihat pada tabel 3 di bawah ini:

Tabel: 3 Hasil Kuis Kemampuan Mengingat Jenis Sendi Pada Manusia

\begin{tabular}{|c|c|c|c|}
\hline No & Kegiatan Pembelajaran & Jumlah Siswa & Persentase Tuntas \\
\hline 1 & Sebelum Penerapan PAKEM & 27 & $50 \%$ \\
\hline 2 & Setelah Penerapan Pakem & 28 & $85 \%$ \\
\hline
\end{tabular}


Berdasarkan tabel 3 di atas maka dapat disimpulkan bahwa penerapan pendekatan belajar Pakem dengan gerak sendi dapat meningkatkan kemampuan mengingat materi pelajaran jenis-jenis sendi manusia pada siswa kelas VIII A SMP Negeri 1 Anggaberi. Berdasarkan tabel 2 di atas hasil kuis mengidentifikasi jenis sendi pada manusia sebelum penerapan pembelajaran Pakem gerak sendi pada kegiatan pembelajaran sebelumnya menunjukkan rata-rata perensantase kemampuan mengingat materi mengidentifikasi materi hanya mencapai nilai $50 \%$, masih di bawah nilai KKM yang ditetapakan pada jenis sendi pada manusia. Selanjutnya pada kegiatan pembelajaran yang menerapkan pendekatan Pakem gerak sendi hasil kuis mengingat materi mengidentifikasi sendi pada manusia persentase analisis hasil kuis mencapai nilai 85\%, di atas KKM yang telah ditetapkan pada materi jenis sendi pada manusia. Peningkatan hasil kuis mengingat materi mengidentifikasi jenis-jenis sendi pada manusia dengan penerapan pendekatan belajar Pakem sesuai dengan pendapat, (Sudirman \& Andriyani, 2002), bahwa hasil belajar dapat diartikan sebagai taraf kemampuan aktual yang bersifat terukur berupa perbuatan yang dicapai dari apa yang dipelajari di sekolah. Hasil belajar merupakan hasil dari suatu interaksi tindak belajar dan tindak mengajar. Dari sisi guru, tindak mengajar diaktiri dengan proses evaluasi hasil belajar. Dari sisi siswa hasil belajar merupakan berakhirnya penggal dan puncak proses belajar. Hasil belajar, untuk sebagian orang adalah berkat tindak guru, suatu pencapaian tujuan pengajaran. Pada bagian lain, merupakan peningkatan kemampuan mental siswa (Dimyati \& Mudjiono, 2006: 3). Dalam bidang studi Fisika hasil belajar yang dimaksud adalah tingkat penguasaan materi pelajaran setelah proses evaluasi diberikan, sebagai tolak ukur kemampuan siswa setelah proses belajar-mengajar berlangsung, dapat disimpulkan bahwa pengukuran hasil belajar berfungsi untuk mengetahui tercapai tidaknya indikator pembelajaran dan mengetahui tingkat penguasaan bahan pelajaran yang harus dikuasai siswa serta untuk mengetahui efektifitas model pengajaran yang digunakan dalam proses belajar-mengajar.

Hal ini juga dimungkinkan karena aktifitas belajar siswa sesuai pendapat para ahli bahwa, aktivitas belajar adalah segala kegiatan yang dilakukan dalam proses interaksi (guru dan siswa) dalam rangka mencapai tujuan belajar. Aktivitas yang dimaksudkan di sini penekanannya adalah pada siswa, sebab dengan adanya aktivitas siswa dalam proses pembelajaran terciptalah situasi belajar aktif, seperti yang dikemukakan Rochman Natawijaya (Depdiknas, 2005 : 31), belajar aktif adalah "Suatu sistem belajar mengajar yang menekankan keaktivan siswa secara fisik, mental intelektual dan emosional guna memperoleh hasil belajar yang berupa perpaduan antara aspek kognitif, afektif dan psikomotor". Hal lain yang dapat meningkatkan hasil belajar siswa adalah pendekatan pembelajaran Pakem, karena pembelajaran Paken adalah bagian daripada pembelajaran bermakna sesuai pendapat para ahli, sehubungan dengan hal ini, belajar bermana dapat diidentifikasi berdasarkan ciri-cirinya, Nasution (2003) memaparkan sebagai berikut : (1) Menjelaskan hubungan atau relevansi bahan-bahan baru dengan bahan-bahan lama. (2) Lebih dulu diberikan ide yang paling umum dan kemudian halhal yang lebih terperinci, (3) Menunjukkan persamaan dan perbedaan antara bahan baru dengan bahan lama, (4) Mengusahakan agar ide yang telah ada dikuasai sepenuhnya sebelum ide yang baru disajikan, (5) Informasi yang dipelajari secara bermakna dapat lebih lama untuk diingat. (6) Informasi yang dipelajari secara bermakna memudahkan proses belajar berikutnya untuk materi pelajaran yang mirip, (7) Informasi yang dipelajari secara bermakna mempermudah belajar hal-hal yang mirip walaupun telah terjadi lupa. Di samping itu, kebermaknaan potensial materi pelajaran bergantung kepada dua faktor, yaitu (1) materi itu harus memiliki kebermaknaan logis, dan (2) gagasan-gagasan yang relevan harus terdapat dalam struktur kognitif peserta didik. Muchlas Samani (2007) mengemukakan bahwa apapun metode pembelajarannya, maka harus bermakna (meaningfull learning). Pembelajaran bermakna merupakan suatu proses mengaitkan informasi baru pada konsep-konsep relevan yang terdapat dalam struktur kognitif seseorang. Struktur kognitif ialah fakta-fakta, konsep-konsep dan generalisasi-generalisasi yang telah dipelajari dan diingat siswa. Suparno (1997) mengatakan, 
bahwa pembelajaran bermakna adalah suatu proses pembelajaran dimana informasi baru dihubungkan dengan struktur pengertian yang sudah dipunyai seorang yang sedang dalam proses pembelajaan. Pembelajaran bermakan terjadi bila siswa mencoba menghubungkan fenomena baru ke dalam struktur pengetahuan mereka. Artinya, bahan pelajaran itu harus cocok dengan kemampuan siswa dan harus relevan dengan struktur kognitif yang dimiliki siswa. Oleh karena itu, pelajaran harus dikaitkan dengan konsep-konsep yang sudah dimilki siswa, sehingga konsep-konsep baru tersebut benar-benar terserap olehnya. Dengan demikian, faktor intelektual emosional siswa terlibat dalam kegiatan pembelajaran.

Best practice ini sesuai dengan hasil penelitian sebelumnya seperti yang pernah dilaksnakan oleh, (Raka Hermawan Kaban dkk, 2020) yang menemukan bahwa, ada pengaruh yang signifikan antara model pembelajaran pakem terhadap hasil belajar kelas V SD Negeri 047176 Sirumbia Tahun Pelajaran 2019/2020, (Rizka Tika Pratiwi, 2017) yang menemukan bahwa penerapan model pakem dengan media education games dapat meningkatkan motivasi dan hasil belajar IPA siswa kelas VII di SMP Taman Dewasa Jetis Yogyakarta Tahun Pelajaran 2016/2017. (Agus Hariwibowo \& Dony Kristiawan, 2016) yang menemukan bahwa, penerapan strategi pembelajaran aktif, kreatif, efektif dan menyenangkan (Pakem) dapat meningkatkan hasil belajar pada mata pelajaran alat ukur elektronika siswa kelas X SMK PGRI Mejayan Caruban.

\section{KESIMPULAN}

Kesimpulan best practice ini adalah bahwa penerapan pendekatan belajar Pakem dengan gerak sendi dapat meningkatkan kemampuan mengingat materi pelajaran jenis-jenis sendi manusia pada siswa kelas VIII A SMP Negeri 1 Anggaberi. Hasil kuis mengidentifikasi jenis sendi pada manusia sebelum penerapan pembelajaran Pakem gerak sendi pada kegiatan pembelajaran sebelumnya menunjukkan rata-rata perensantase kemampuan mengingat materi mengidentifikasi materi hanya mencapai nilai 50\%, masih di bawah nilai KKM yang ditetapakan pada jenis sendi pada manusia, dan mengalami peningkatan setelah kegiatan pembelajaran yang menerapkan pendekatan Pakem gerak sendi hasil kuis mengingat materi mengidentifikasi sendi pada manusia persentase analisis hasil kuis mencapai nilai $85 \%$, di atas KKM yang telah ditetapkan pada materi jenis sendi pada manusia.

\section{DAFTAR PUSTAKA}

Dahar, Ratna Wilis. (1996). Teori-teori Belajar. Bandung: Erlangga

Depdiknas. (2005). Pembinaan Profesionalisme Tenaga pengajar (Pengembangan Profesionalisme Guru). Jakarta: Direktorat Jenderal Pendidikan dasar dan Menengah Direktorat Pendidikan Lanjutan Pertama Depdiknas.

Dimyati \& Mudjiono. (2006). Belajar dan Pembelajaran. Jakarta: PT Rineke Cipta.

Lusia GS \& Sukadari. (2020). Peningkatan Motivasi Belajar, Kaaktifan, dan Prestasi Belajar Ekonomi Siswa Kelas XI MIPA 3 SMA Stella Duce 1 Yogyakarta Melalui Metode Personal Interaction Tapel 2016/2017. Sukoharjo: CV Sintesia.

Made Pidarta. (2007). Landasan Kependidikan. Jakarta: Rineka Cipta.

Muchlas, Samani (2007). Pendidikan Bermakna: Integrasi Life Skill-KBK-CTLMBS; Surabaya: SIC.

Nasution. (2003). Berbagai Pendekatan dalam Proses Belajar dan Mengajar. Jakarta; Bumi Aksara.

Paul Suparno. (1997). Filsafat Konstruktivisme dalam Pendidikan. Yogyakarta: Kanisius. Roestiyah. (1989). Strategi Belajar Mengajar, Jakarta: PT. Rineka Cipta.

Sudjana Nana. (1984). Dasar-dasar Proses Belajar Mengajar, Bandung: Sinar Baru Algensindo.

Sudirman (2002). Ilmu Pndidikan, Bandung : Remaja Rosdakarya.

Suryosubroto. (1997). Proses Belajar Mengajar di Sekolah, Jakarta:PT. Rineka Cipta. 
Vol. 1 No. 3 November 2021 e-ISSN : 2797-1031 | p-ISSN : 2797-0744

Wina Senjaya. (2006). Strategi Pembelajaran Berorientasi Proses Standar Proses Pendidikan, Jakarta : Kencana Prima. 